\title{
EMPIRICAL SEDIMENT TRANSPORT MODELS BASED ON INDOOR RAINFALL SIMULATOR AND EROSION FLUME EXPERIMENTAL DATA
}

\author{
Hafzullah Aksoy ${ }^{1}$, Ebru Eris ${ }^{2 *}$, Gokmen Tayfur ${ }^{3}$ \\ ${ }^{1}$ Hydraulics Division, Department of Civil Engineering, Istanbul Technical University, 34469 Maslak, Istanbul, Turkey \\ ${ }^{2}$ Department of Civil Engineering, Ege University, 35100 Bornova, Izmir, Turkey \\ ${ }^{3}$ Department of Civil Engineering, Izmir Institute of Technology, Urla, Izmir, Turkey \\ Received: 3 February 2016; Revised: 18 May 2016; Accepted: 18 May 2016
}

\begin{abstract}
Land degradation processes start with accelerated runoff and sediment delivery. In this study, rainfall-runoff induced sediment transport is investigated using data from an indoor laboratory experimental setup consisting of a rainfall simulator and an erosion flume. The data are analysed to develop empirical models using sediment discharge, slope, flow discharge, rainfall intensity and sediment size. Fine and medium sands are considered as bare soil in experiments. Four rainfall intensities $\left(45,65,85\right.$ and $\left.105 \mathrm{~mm} \mathrm{~h}^{-1}\right)$ are applied with combinations of lateral and longitudinal slopes of 5\%,10\%, 15\% and 20\%. Eighty experiments are conducted. Flow is measured, and sediment within flow is separated and weighted. Experimental data are used for developing empirical models through multiple regression with parameters optimized by genetic algorithm. Results show that slope is the main contributing variable to the sediment transport over hillslopes. Accommodating variables among slope, rainfall intensity, flow discharge and median diameter of sediment as independent variables, one-variable, two-variable and four-variable models are developed considering also that higher number of parameters increases the performance of the model with higher cost of parameterization. Copyright (C) 2016 John Wiley \& Sons, Ltd.
\end{abstract}

KEY WORDS: empirical model; erosion flume; rainfall simulator; sediment transport rate; soil erosion

\section{INTRODUCTION}

Soil erosion from hillslopes in hydrological watersheds affects land degradation, which is not only an important driving force affecting the landscape but also one of the most serious environmental problem that threats the cultivated soils all over the World (Keesstra et al., 2016b; Prosdocimi et al., 2016). Land degradation is due to a complex mix of causes; some may be natural and some human-induced (Xu \& Zhang, 2014; Xie et al., 2015). Increase in soil erosion not only causes soil quality degradation because of loss of topsoil as a result of soil quality degradation in an irreversible direction but also lead to catastrophic floods, droughts and famine threatening food and environmental security worldwide (Erkossa et al., 2015; Musinguzi et al., 2015; Stanchi et al., 2015; Tsozué et al., 2015; Ochoa et al., 2016). It is important to keep in mind that the transportation of sediment to water bodies is accompanied by loss of nutrients from farmlands, which results in infertile farmlands and eutrophicated freshwater (Vanacker et al., 2003), meaning also that croplands are lost because of soil erosion as the soil loss rate is much faster than the soil renewal rate (Pimentel, 2006; Bravo-Espinosa et al., 2014; Li et al., 2014; Wang et al., 2016). Because of these concerns, a scientific basis can be established for land management; thus, the ecological environment and sustainable use of land

*Correspondence to: E. Eris, Department of Civil Engineering, Ege University, 35100 Bornova, Izmir, Turkey.

E-mail: ebru.eris@ege.edu.tr resources can be improved by analysing the relationship between soil physical properties and land use, and determining the spatial variability and distribution of soil physical properties at watershed scale (Wang \& Shao, 2013).

Sediment transport consists of motion of soil particles detached by factors such as rainfall, runoff and wind and transported within flow to be finally deposited at a downstream section of the river with a lower topographical slope. The transportation of pollutants detached to fine sediment particles eroded from fertile agricultural lands resulting in water quality problems has increased the importance of erosion and sediment transport by surface flows (TrujilloGonzález et al., 2016). From the Hydraulic Engineering point of view, severe soil erosion led to large amount of sediment discharged into rivers (Palazon et al., 2014; Ben Slimane et al., 2015; Ferreira et al., 2015) and possibly deposited in the reservoir; therefore, it harms dams and reservoirs and eventually makes them unusable for their intended purposes. Therefore, the importance of erosion and sediment transport is well recognized and has been the topic of research for many decades for which numerous computational methods have been developed for quantification of sediment transport (Tayfur, 2001; Aksoy \& Kavvas, 2005; Wu \& Chen, 2012; Pak et al., 2015). For the same reason, understanding better the historical changes of environment and current status of soil erosion and conservation is greatly helpful for watershed management, soil erosion control and ecological restoration (Cerda et al., 2016; Keesstra et al., 2016a). 
Sediment transport can be studied by analysing a time series of sediment discharge (Phien \& Arbhabhirama, 1979; Phien, 1981); performing regression analysis (Ziadat \& Taimeh, 2013); employing empirical approaches and traditional equations (Bogardi, 1974; Garde \& Ranga Raju, 1977); monitoring, sampling and surveying (Ziegler et al., 2001; Araujo et al., 2006; Lieskovsky \& Kenderessy, 2014); and using the remote sensing and geographical information systems (GIS) (Baban \& Yusof, 2001; Leh et al., 2013; Biswas et al., 2015). In addition, the process-based distributed modelling approach has been used (Kavvas et al., 2006; Lieskovsky \& Kenderessy, 2014), although in some cases, a contrasting disagreement has shown between the estimation made with the models and the erosion rates found in the field (Boix-Fayos et al., 2005). Also, soft computational techniques such as artificial neural networks (Tayfur, 2002) were considered for estimation purposes.

Sediment transport models can be either empirical, conceptual or process-based (Aksoy \& Kavvas, 2005). Empirical models might make estimates of sediment rates changing within orders of magnitude because of the low probability of similarity between the study area and the experimental site from which the data are taken for the model development. Compared with conceptual and process-based models, usually, less number of parameters is used in empirical models. Therefore, a conceptual or a process-based model might be expected to approach the reality with a higher cost for parameterization and data requirement. This becomes a challenge especially in ungauged basins where there is no sufficient data. Another challenge could be related to the transport capacity of overland flow that initiates erosion and sediment transport within watershed and water courses. Difficulties in the calibration and validation stages of models are other issues to be considered (Aksoy, 2015). Despite of all these challenges and difficulties, sediment transport models developed at hillslope and watershed scales (Zhang et al., 1996; Aksoy \& Kavvas, 2005; Arguelles et al., 2014; Zuliziana et al., 2015) have enhanced the understanding of the mechanism of sediment transport under varying conditions over the hillslope or watersheds. When the GIS technology is combined with the sediment transport modelling, it is possible to derive an effective way to map spatial distribution of soil erosion risks in large areas to be used in assisting conservation management and land use planning (Mandal \& Sharda, 2013; Dai et al., 2015).

As a further contribution to the sediment transport problem, this study investigates the rainfall-runoff induced sediment transport mechanism by using data from a rainfall simulator with an erosion flume filled with bare sand as soil. Four different rainfall intensities were applied on the flume with adjustable lateral and longitudinal slopes. In this particular case, experimental data were analysed to develop empirical regression equations on flow discharge, topographical slope, rainfall intensity and sediment size for using in the calculation of sediment discharge.

\section{MATERIALS AND METHODS}

The use of flumes under simulated rainfall is worldwide known, and it is accepted that they increase the accuracy and the number of high-quality measurements (MorenoRamón et al., 2014; Lassu et al., 2015; Sadeghi et al., 2015). Experimental design used in this study [detailed in Aksoy et al. (2013)] consists of an indoor laboratory rainfall simulator and an erosion flume (Figure 1a). To ensure uniform distribution of rainfall over the flume, the simulator was equipped (depending on the rainfall intensity) with four (or five) VeeJet 8030, 8050, 8060 and 8070 type nozzles. The nozzles were placed $125-$ to $145-\mathrm{cm}$ apart from each other depending again on the applied rainfall intensity. The nozzles were installed on a periodically oscillating bar at a height of $260 \mathrm{~cm}$ from the flume bed to ensure the terminal velocity of rain drops. Oscillation of the bar is achieved by a motor, and its periodicity is adjusted by a frequency converter. Water is supplied from a water tank and pumped up through a main water pipe divided into four (or five) pipes depending on the number of nozzles used. At the end of each pipe, VeeJet nozzles are replaced before which pressure gauges are attached.

The erosion flume is $136-\mathrm{cm}$ wide, $650-\mathrm{cm}$ long and $17-$ $\mathrm{cm}$ deep. The flume slope can be adjusted for 5\%, $10 \%$, $15 \%$ and $20 \%$ at both lateral and longitudinal directions (Aksoy et al., 2012). Laboratory flumes with adjustable lateral and longitudinal slopes are very rare in the literature. In order to conduct experiments, the flume was first filled with medium-size uniform sand of median diameter $0.45 \mathrm{~mm}$. Four different rainfall intensities were applied; $r=45,65$, $85,105 \mathrm{~mm} \mathrm{~h}^{-1}$. Ten experiments were performed for each of the rainfall intensities, considering combinations of lateral and longitudinal slopes ( $S_{y}$ and $S_{x}$, respectively) based on the assumption that longitudinal slope cannot be milder than the lateral slope. After each experiment, the sand surface is adjusted in parallel with the flume slope such that the sand surface slope is assumed to be the same as the flume bed slope. This means any slope given to the flume is considered to be the surface slope. After completing all combinations of slopes and rainfall intensities (40 experiments) for the medium sand, a new series of 40 experiments were performed for fine sand of $0.15 \mathrm{~mm}$ median diameter.

The performance evaluation of the network of nozzles to simulate rainfall was given by Aksoy et al. (2012) who stated that natural rainfall conditions were simulated with sufficient accuracy for the purpose of laboratory-scale sediment transport measurements. Four VeeJet 8030 nozzles were installed on the oscillating bar for $45 \mathrm{~mm} \mathrm{~h}^{-1}$ of rainfall intensity and four VeeJet 8050 nozzles for $65 \mathrm{~mm} \mathrm{~h}^{-1}$. Five VeeJet 8060 and five VeeJet 8070 nozzles were used for rainfall intensities of 85 and $105 \mathrm{~mm} \mathrm{~h}^{-1}$, respectively. The number of and the distance between the nozzles were decided to ensure the uniform distribution of rainfall on the flume. Also, the nozzles were pressurized such that rainfall sprayed out of each nozzle intersects rainfall of two neighbouring nozzles to secure uniformly distributed rainfall 


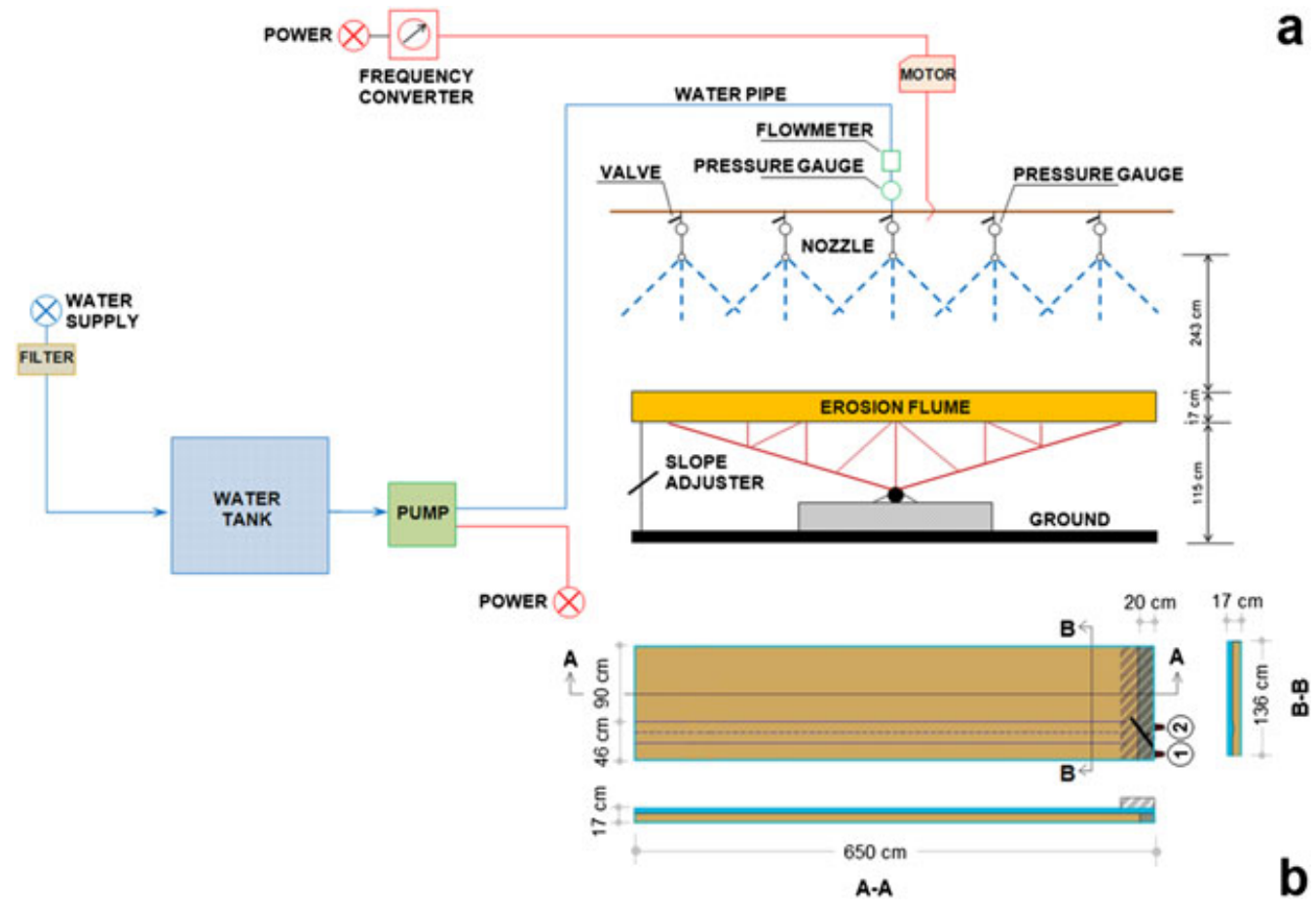

Figure 1. (a) Sketch of rainfall simulator and erosion flume, (b) plan view of erosion flume. [Colour figure can be viewed at wileyonlinelibrary.com]

over the flume. After several initial experiments, characteristics in Table I were found appropriate for the aim of the study ensuring the uniformity of the rainfall at the desired intensity.

Spatial uniformity of the rainfall drops is evaluated by uniformity coefficient $\left(C_{u} C\right)$ defined by Christiansen (1941) in percent as follows:

$$
C_{u} C=\left(1-\frac{\sum_{1}^{N}\left\lfloor x_{i}-\bar{x}\right\rfloor}{N \bar{x}}\right) 100
$$

in which $x_{i}$ is rainfall amount at location $i, \bar{x}$ is average amount of rainfall and $N$ number of points where measurement cups are placed over the flume to collect rainfall. The $C_{u} C$ is a useful index of spatial uniformity of rainfall. The more uniform the pattern of rainfall is, the closer $C_{u} C$ approaches to $100 \%$. A rainfall can be considered uniform

Table I. Nozzle scheme on the oscillating bar and corresponding rainfall characteristics

\begin{tabular}{lccccc}
\hline $\begin{array}{l}\text { VeeJet } \\
\text { nozzle }\end{array}$ & $\begin{array}{c}\text { Nozzle } \\
\text { equivalent } \\
\text { orifice } \\
\text { diameter } \\
(\mathrm{mm})\end{array}$ & $\begin{array}{c}\text { Pressure } \\
(\mathrm{kPa})\end{array}$ & \multicolumn{2}{c}{$\begin{array}{c}\text { Flowmeter } \\
\text { reading }\end{array}$} & $\begin{array}{c}\text { Rainfall } \\
\text { intensity } \\
\left(\mathrm{mm} \mathrm{h}^{-1}\right)\end{array}$ \\
\cline { 4 - 4 } & & $1 \mathrm{~min}^{-1}$ & $\mathrm{~mm} \mathrm{~h}^{-1}$ & \\
\hline 8030 & $3 \cdot 4$ & 40 & $19 \cdot 7$ & $133 \cdot 7$ & 45 \\
8050 & $4 \cdot 4$ & 42 & $22 \cdot 7$ & $154 \cdot 1$ & 65 \\
8060 & $4 \cdot 8$ & 33 & $27 \cdot 1$ & 183.9 & 85 \\
8070 & $5 \cdot 2$ & 48 & $35 \cdot 6$ & 241.6 & 105 \\
\hline
\end{tabular}

when $C_{u} C$ is higher than $80 \%$ (Moazed et al., 2010). $C_{u} C$ changed from $82 \%$ to $89 \%$ for rainfall patterns in this study. The raindrop fall height allowed the median size raindrops to hit the soil with a velocity deviated from the terminal velocity with a relative error between $6 \%$ and 15\% (Aksoy et al., 2012). The rainfall granulometry pattern was determined to calculate raindrop energy when each drop hits the ground by using the flour pellet method (Kincaid et al., 1996; Sadeghi et al., 2013).

The upland area in a watershed is formed from natural slopes with a microtopographical structure that consists of rills and interrill areas, although in some cases in hydrological modelling practice, they are smoothed over the hillslope (see the ANSWERS model of Beasley et al., 1980 as an example of no-rilling). Flow characteristics in a rill and interrill area are different from each other. Not only flow but also infiltration and sediment transport is affected by the microtopography. Interrill erosion is a rainfall dominated process, whereas erosion in the rill is mostly defined by flow detachment. It has been shown experimentally by Govindaraju et al. (1992) that erosion in rills is, at least, one order of magnitude greater than erosion on interrill areas. Pre-forming the rill before initiating the experiment has already been applied in the literature (Gilley et al., 1992). Consequently, erosion flume in this study was constructed to simulate the microtopography of the hydrological watershed that controls the spatial distribution of overland flow, infiltration and sediment transport (Kirkby et al., 1998).

In experiments, the sand within the flume was given an initial microtopography with a triangular cross-section 
rill, 2-cm deep and 26-cm wide contributed by an interrill area. The rill was longitudinally pre-formed on the righthand side of the flume before the rainfall was applied (Figure 2). The view of the erosion flume (Figure 1b) corresponds to the rectangular area selected from the watershed hillslope. With giving a lateral slope to the erosion flume, most of the interrill area contributes flow in the rill. The contributing area changes with the lateral slope given to the flume. A small portion of the interrill area closer to the downstream part of the flume flows to the channel directly. Two outlets were therefore formed on the flume (Figure 1b): outlet 1 is used for collecting flow from interrill area and rill together while outlet 2 is used for direct contribution from the interrill area to the channel (Aksoy et al., 2012).

A while after rainfall was applied on the erosion flume, soil became saturated, and surface flow was observed in the rill. No measurement was taken until surface flow was observed and reached the rill outlet (Outlet 1) of the flume. Rainfall was applied for 15 more minutes after the surface flow at the flume outlet was recorded. Measurements were taken by means of cups every $1 \mathrm{~min}$ or at time intervals as short as $10-15 \mathrm{~s}$ depending on how fast the cups were filled. Measurements were continued for 10 more minutes after the rainfall was ceased so that the recession curve of the hydrograph and sedigraph could be constructed. The total time span for measurements was $25 \mathrm{~min}$.

The cups used for the measurement were left to stay 1 day at rest for sediment to settle down within the mixture of water and sediment. The day after each experiment, the total volume and total mass were first measured for each measurement cup; water in the cup was poured carefully out, and wet sediment mass was measured. Regression equations already developed from earlier experiments between ovendry sediment and wet sediment characteristics for medium and fine sands were used in converting the measured wet sediment mass to the oven-dry sediment volumetric concentration $\left(C_{S}\right)$, the ratio of oven-dry sediment volume to the total volume. Figure 3 shows scatter plots between volumetric sediment concentration and the ratio of total wet sediment

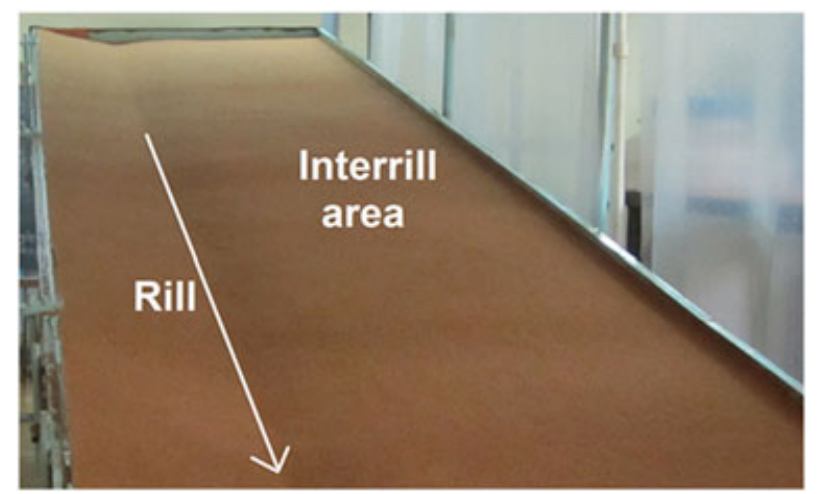

Figure 2. Pre-forming rill before the rainfall application. [Colour figure can be viewed at wileyonlinelibrary.com]

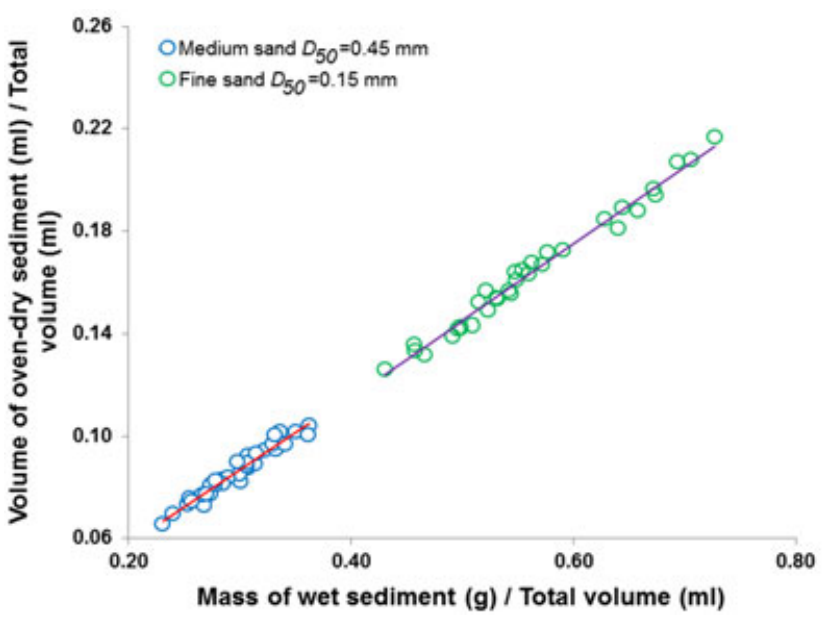

Figure 3. Scatter plots between volumetric sediment concentration and the ratio of total wet sediment mass to total volume for medium sand $\left(D_{50}=0.45 \mathrm{~mm}\right)$ and fine sand $\left(D_{50}=0.15 \mathrm{~mm}\right)$. [Colour figure can be viewed at wileyonlinelibrary.com]

mass $\left(M_{\text {sed,wet }}\right)$ to the total volume $\left(V_{\text {total }}\right)$. Regression equations developed, respectively, for the medium and fine sands are as follows:

$$
\begin{aligned}
& C_{s}=100\left(0.2895 M_{\text {sed }, \text { wet }} / V_{\text {total }}\right) \\
& C_{s}=100\left(0.2912 M_{\text {sed }, \text { wet }} / V_{\text {total }}\right)
\end{aligned}
$$

Flow discharge $(q)$ in $\left[\mathrm{ml} \mathrm{s}^{-1}\right]$ and sediment discharge $\left(q_{s}\right)$ in $\left[\mathrm{g} \mathrm{s}^{-1}\right.$ ] were calculated simply by dividing the volume of flow and mass of sediment, respectively, by the corresponding sampling time interval.

\section{Empirical Models}

Sediment transport is related to the transport capacity of flow that can be determined by using different approaches, namely, shear stress, stream power and unit stream power (Tayfur, 2002; Zhang et al., 2009). According to Julien (2010), sediment transport is a function of the geometry, flow, fluid and soil characteristics as follows:

$$
q_{s}=f u n c\left(S, q, r, L, \rho, v, \frac{\tau_{c}}{\tau_{0}}\right)
$$

Where: $q_{s}$ is sediment transport, $S$ is surface slope, $q$ is discharge, $r$ is rainfall intensity, $L$ is length of the runoff over the hillslope, $\rho$ is mass density of fluid, $v$ is kinematic viscosity of fluid, and $\tau_{c}$ and $\tau_{0}$ are, respectively, the critical and applied boundary shear stresses. A relationship considering the most important variables into account was developed by Julien \& Simons (1985) to accommodate the effective variables as follows:

$$
q_{s}=\alpha S^{\beta} q^{\gamma} r^{\delta}\left(1-\frac{\tau_{c}}{\tau_{0}}\right)^{\varepsilon}
$$

Where: $\alpha$ is a coefficient and $\beta, \gamma, \delta, \varepsilon$ are exponents to be determined from laboratory or field experiments. When $\tau_{c}$ 
is very small compared with $\tau_{0}$, Equation 5 can be expressed as follows:

$$
q_{s}=\alpha S^{\beta} q^{\gamma} r^{\delta}
$$

which is the version addressed by Prosser \& Rustomji (2000) for the sediment transport capacity. From examination of data from a number of laboratory flume-based, field plot-based and river-based studies, Prosser \& Rustomji (2000) found that $\beta$ and $\gamma$ exponents in Equation (6) were bounded by 0.5 and $2 \cdot 0$, as lower and upper limits, respectively. When a single value is desired, a median value of 1.4 can be used for both exponents. The sediment transport capacity $\left(T_{c}\right)$ of overland flow was also found to be proportional to the overland flow discharge $(q)$ only, as $T_{c} \sim q^{\gamma}$, where $\gamma$ ranged between 1·2-1·5. The sediment concentration $\left(C_{s}\right)$ in the runoff becomes $C_{s} \sim q^{\gamma-1}$ (Novotny \& Chesters, 1989). Abrahams et al. (1998) obtained a regression equation for the transport capacity of overland flow by combining results of laboratory experiments and pointed out that the transport capacity is a challenging issue in the sediment transport models. Although it has been shown in some cases that models may not behave considerably different from each other when different transport capacity equations are used (Haregeweyn et al., 2013), selection of the transport capacity equation is a major issue in the development of the sediment transport models.

In this study, regression-based empirical models were developed for sediment transport as an analogy to the sediment transport capacity equations. For this aim, a simple correlation analysis is made between the affecting variables; the dependent variable, $q_{s}$, and the independent variables, $S, q, r$ and $D_{50}$ as shown in Table II. Different combinations of independent variables are used in order to estimate sediment discharge $\left(q_{s}\right)$. As an additional independent variable, the median particle diameter $\left(D_{50}\right)$ should be noticed. Significance of the models and model parameters is tested with the $F$-tests and $t$-tests, respectively. When the $F$ (or $t$ ) statistics calculated for each model (or parameter) is larger than the corresponding critical value, the model (or parameter) is considered significant. The tests show that all independent variables in Table II have significant contribution to the variability in the dependent variable, thus all should be included in the regression model. By setting the critical significance value at $0 \cdot 10$, Models $1-4$ are, respectively, proposed as follows:

$$
\begin{gathered}
q_{s}=\alpha S^{\beta} \\
q_{s}=\alpha S^{\beta} r^{\delta}
\end{gathered}
$$

Table II. Correlation coefficients between the variables considered (boldface numbers show statistically significant relationships at significance level of 0.05)

\begin{tabular}{lrrrr}
\hline & $q_{s}$ & $S$ & $q$ & $r$ \\
\hline$S$ & $\mathbf{0 \cdot 8 0 0}$ & & & \\
$q$ & $\mathbf{0 \cdot 8 4 1}$ & $\mathbf{0 \cdot 4 5 0}$ & & \\
$r$ & $\mathbf{0 \cdot 4 4 4}$ & $0 \cdot 000$ & $\mathbf{0 \cdot 7 8 7}$ & \\
$D_{50}$ & -0.138 & 0.000 & $0 \cdot 004$ & -0.000 \\
\hline
\end{tabular}

$$
\begin{gathered}
q_{s}=\alpha S^{\beta} q^{\gamma} \\
q_{s}=\alpha S^{\beta} q^{\gamma} r^{\delta} D^{\theta}{ }_{50}
\end{gathered}
$$

in which $S$ is the resultant surface slope in the flow direction to be computed using

$$
S=\left(S_{x}^{2}+S_{y}^{2}\right)^{1 / 2}
$$

as given by Tayfur (2001).

\section{Optimization of Model Parameters by Genetic Algorithm}

Genetic algorithm (GA) as a nonlinear search and optimization method inspired by biological processes of natural selection and the survival of the fittest was used for the optimization of the model parameters. GA makes relatively few assumptions and do not rely on any mathematical properties of the functions such as differentiability and continuity, and this makes it more generally applicable and robust (Liong et al., 1995; Goldberg, 1989). Basic units of GA consist of 'bit', 'gene', 'chromosome' and 'gene pool'. Gene consisting of bits [0 and 1] represents a model parameter (or a decision variable) to be optimized. The combination of genes forms the chromosome, each of which is a possible solution for each variable. Finally, set of chromosomes form the gene pool. The main GA operations basically consist of 'generation of initial gene pool', 'evaluation of fitness for each chromosome', 'selection', 'cross-over' and 'mutation'. The details of GA can be obtained from Goldberg (1989) and Tayfur (2012), among others.

Genetic algorithm can minimize (or maximize) an objective function under some specified constraints. For the purpose of this study, the GA was employed to obtain optimal values of the parameters and coefficients of the models as in Equations (7-10) by minimizing the mean absolute error $(M A E)$ objective function:

$$
M A E=\frac{1}{N} \sum_{1}^{N}\left|q_{S_{\text {model }}}-q_{S_{\text {measured }}}\right|
$$

where $N$ is number of observations, $q_{S_{\text {model }}}$ is model-produced sediment discharge and $q_{S_{\text {measured }}}$ is measured sediment discharge.

\section{RESULTS AND DISCUSSION}

Developed models were calibrated and validated by employing the GA optimization method for the aim of obtaining optimal values of the coefficients and exponents $(\alpha, \beta, \gamma, \delta, \theta)$ in the proposed regression models (Equations 7-10). Experimental data collected from the rainfall simulator and erosion flume were considered for this aim. Randomly selected 64 out of 80 experimental data were used at the calibration stage of each model in Table III to assign optimal values for the coefficients and exponents. Data from the remaining 16 experiments were used for the purpose of validation. As the performance measures, the coefficient of determination, $R^{2}, M A E$ and root mean 
Table III. Calibrated model parameters and performance characteristics for calibration and validation stages

\begin{tabular}{|c|c|c|c|c|c|c|c|c|c|c|c|c|}
\hline \multirow[t]{2}{*}{ Model } & \multirow[t]{2}{*}{ Equation } & \multicolumn{5}{|c|}{ Parameters } & \multicolumn{3}{|c|}{ Calibration } & \multicolumn{3}{|c|}{ Validation } \\
\hline & & $\alpha$ & $\beta$ & $\gamma$ & $\delta$ & $\theta$ & $R^{2}$ & RMSE & $M A E$ & $R^{2}$ & RMSE & $M A E$ \\
\hline 1 & $q_{s}=\alpha S^{\beta}$ & $0 \cdot 805$ & 1.674 & & & & $0 \cdot 61$ & $50 \cdot 2$ & $37 \cdot 5$ & $0 \cdot 82$ & $45 \cdot 9$ & $32 \cdot 6$ \\
\hline 2 & $q_{s}=\alpha S^{\beta} r^{\delta}$ & 0.027 & 1.644 & & $0 \cdot 838$ & & 0.87 & $28 \cdot 3$ & 21.9 & 0.95 & $22 \cdot 0$ & $18 \cdot 5$ \\
\hline 3 & $q_{s}=\alpha S^{\beta} q^{\gamma}$ & 0.073 & 1.081 & 0.919 & & & 0.95 & $18 \cdot 4$ & $13 \cdot 8$ & 0.96 & $22 \cdot 1$ & $16 \cdot 5$ \\
\hline 4 & $q_{s}=\alpha S^{\beta} q^{\gamma} r^{\delta} D_{50}{ }^{\theta}$ & 0.036 & $1 \cdot 146$ & 0.899 & 0.073 & $-0 \cdot 194$ & 0.97 & $13 \cdot 6$ & $10 \cdot 7$ & 0.98 & $14 \cdot 5$ & $10 \cdot 9$ \\
\hline
\end{tabular}

square error (RMSE) were also given in Table III from which it is seen that increasing number of parameters increases the performance of the model with higher cost of parameterization. This has been the case in both the calibration and validation stages.

In Model 1, only topographical slope is considered as the factor affecting sediment transport with which about twothirds of the variance is explained at the calibration stage and more than $80 \%$ at the validation. This points the topography as a key factor in controlling soil processes due to the fact that soil loss generally increases as slope steepness increases (Seutloali \& Beckedahl, 2015; Arjmand Sajjadi \& Mahmoodabadi, 2015; Pereira et al., 2016; Vaezi et al., 2016). In an earlier example, Cerda \& Garcia-Fayos (1997) demonstrated the influence of slope on sediment and found that as slope increases, overland flow velocity increases such that the greater surface velocity increases the erosive power and the flow transport capacity to carry sediments. Therefore, slope has a clear positive effect in controlling soil erodibility and erosion rates (Cerda \& GarciaFayos, 1997); thus, in general, sediment discharge increases as the slope increases. The slope is a key factor also in the transport capacity of overland flow (Prosser \& Rustomji, 2000; Haregeweyn et al., 2013). The experimental setup in this study can be given both longitudinal and lateral slopes as explained earlier. Using experimental data from this setup, Aksoy et al. (2013) found that slope affected sediment discharge and concentration; longitudinal slope being more effective than the lateral slope.

Models 2 and 3 with two independent variables each, $S$ and $r$ for Model 2 (Equation 8) and $S$ and $q$ for Model 3 (Equation 9), show better performances than Model 1 with the additional variable. Explained variance increased to $87 \%$ and $95 \%$ for Models 2 and 3, respectively, at the calibration stage, and both models performed almost similarly at the validation in terms of the explained variance. Higher $R^{2}$ and lower RMSE and MAE of Model 3 compared with Model 2 give slightly higher impact to discharge against rainfall intensity as an independent variable in addition to the topographical slope, thus show that flow discharge is more definitive than rainfall intensity in the estimation of sediment transport. This has been shown by Grismer (2011) who found that runoff was sensitive to the slope change to become a dominant erosive agent beyond some threshold inclination. Finally, as flow discharge $(q)$ and slope are found to be the most dominating variables and $q$ is a function of the upslope contributing area, it can be stated that sediment discharge is evaluated completely by topographic factors.

When the four-variable Model 4 is considered, its performance becomes the highest among the proposed models unlike the one-variable Model 1 with the worst performance. This is an expected result because of the higher number of parameters involved in the former model and less in the latter. Higher number of parameters makes the model less parsimonious for which higher cost of parameterization becomes unavoidable in terms of statistical errors to be made in the estimation of each parameter. Models do not offer a considerable improvement in estimating $q_{s}$ when $D_{50}$ is added to Equations ( 8 and 9). As can be seen in Table II, correlation coefficient between $D_{50}$ and $q_{s}$ is already low. However, when all independent variables are used in the model, without considering the interdependence, $D_{50}$ becomes significant and therefore it appears in Equation 10.

Scatter plots of the simulated sediment transport rates $\left(q_{s}\right)$ (Equations 7-10) versus the experimental observations are presented in Figure 4 for the calibration stage of each model. It is seen that the best estimations are obtained by the use of Model 4 (Equation 10) and Model 3 (Equation 9) with the determination coefficients of 0.97 and 0.95 , respectively (Table III). As stated before, the performance of the models

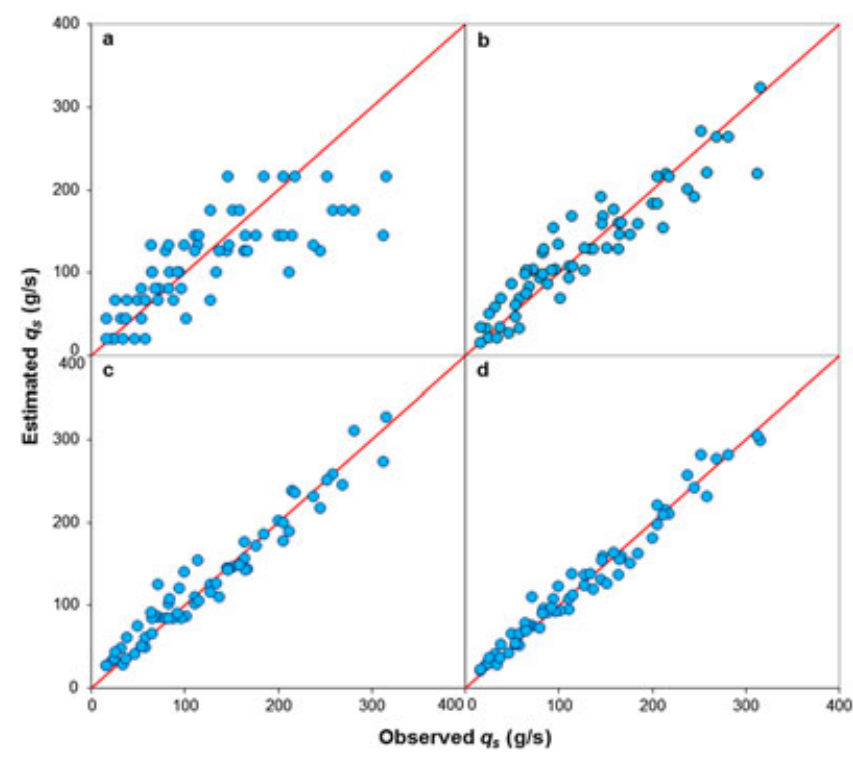

Figure 4. Scatter diagrams of measured and estimated sediment transport rates using calibration data for (a) Model 1, (b) Model 2, (c) Model 3, and (d) Model 4. [Colour figure can be viewed at wileyonlinelibrary.com] 


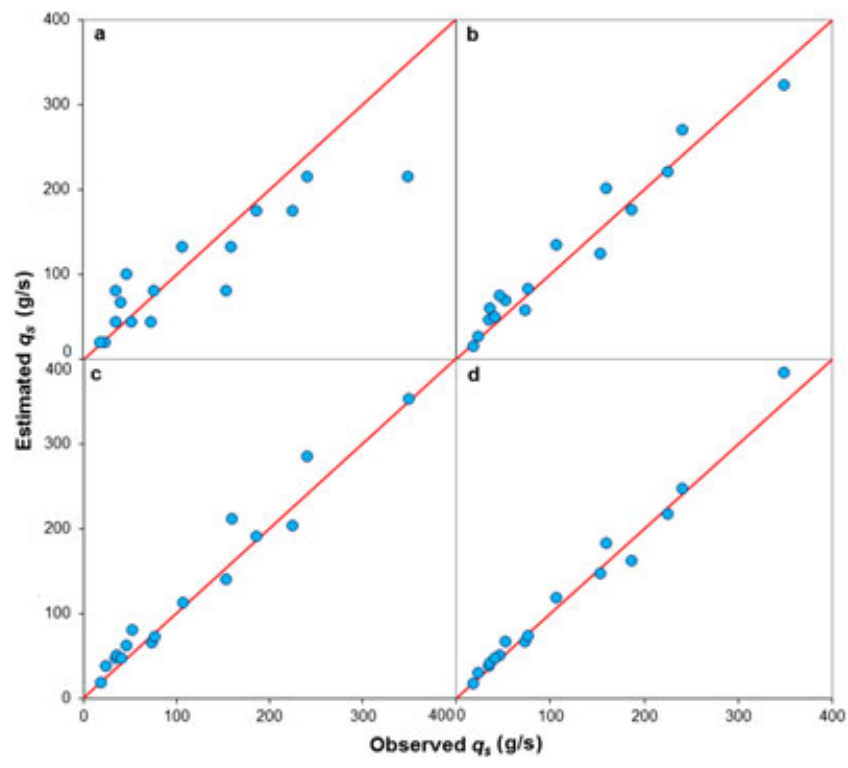

Figure 5. Scatter diagrams of measured and estimated sediment transport rates using validation data for (a) Model 1, (b) Model 2, (c) Model 3 , and (d) Model 4. [Colour figure can be viewed at wileyonlinelibrary. com]

increases as higher number of parameters is used in the model structure. Employing only the slope as the independent variable (Model 1, Equation 7) does not provide, although sufficient, good results (Figure 4a). However, it is important to mention that it is simpler than the other three models because the only variable required is the easily available topographical slope. Figure $4 \mathrm{~b}$ shows that Model 2 provides better estimations than Model 1 by using slope $(S)$ and rainfall intensity $(r)$ as independent variables, which are both relatively easier to measure than the flow discharge and the sediment granulometry, that is, the median diameter. Model 3 , which is based on the slope and flow discharge, provides fairly good estimates (Figure 4c). Estimations become much better when rainfall and particle diameter were also incorporated into the model (Model 4, Figure 4d).

Figure 5 shows the sediment estimation at the validation stage for each model to be considered together with the performance criteria in Table III. When the performance criteria are considered, the order of the performance of Models 1-4 (Equations 7-10) stays the same as in the calibration stage, that is, the best performance was shown by Model 4 (Equation 10) with the highest number of independent variables while the worst case was obtained by Model 1 (Equation 7) with the least number of independent variables. Adding rainfall intensity to the slope in Model 2 (Equation 8) made a significant change (Figure 5b, Table III) compared with Model 1 (Equation 7). Adding discharge along with slope into the independent variables of the model provides much better results compared with Model 2. The distribution of data is fairly good around the best-fit line. However, including $D_{50}$ along with the other three independent variables further improved the results.
Despite their good performance, the applicability of the developed models should be considered within the range of experimental data. Therefore, for the future, it is possible to extend the applicability of the models by conducting experiments to obtain data within a wider range. The range of the soil size and its non-cohesiveness has the most important impact in the applicability of the models. Therefore, future studies can be considered to be scheduled for experiments using cohesive or non-cohesive soils within a wider range of size.

\section{CONCLUSION}

Based on rainfall-runoff induced sediment transport experimental data within an intensity range of rainfall applied on bare soil simulated by uniform sand in a laboratory erosion flume with adjustable longitudinal and lateral slopes, four empirical models that use slope, flow discharge, rainfall intensity and sediment size either individually or combined are developed. Slope was found to be a unique independent variable when a one-variable equation is considered. The performance of the slope-dependent model is found promising. Rainfall intensity or flow rate can be considered as the second independent variable in addition to the slope for a better performance, flow discharge being more definitive than the rainfall intensity in quantifying the sediment discharge. Best performance is obtained by the least parsimonious four-variable model; however, it is important to notice that higher cost in terms of parameterization is needed. It is also important to note that the developed models are all empirical and valid only for the range of experimental data used in this study. The models should not be extrapolated beyond the lower and upper limits of the data set considered. Experiments on a wider ranges of sediment size, rainfall intensity and slopes can be conducted for the generalization of results and concluding remarks of this study.

\section{ACKNOWLEDGEMENT(S)}

This study is based on the international project 'Development of a hillslope-scale sediment transport model' bilaterally supported by TUBITAK (Scientific and Technical Research Council of Turkey, project no. 108Y250) and Korean NRF (National Research Foundation). Two reviewers and the editor have contributed to this paper with constructive comments and suggestions for which the authors deeply thank.

\section{REFERENCES}

Abrahams AD, Li G, Krishnan C, Atkinson JF. 1998. Predicting sediment transport by interrill overland flow on rough surfaces. Earth Surface Processes and Landforms 23: 1087-1099. DOI:10.1002/(SICI)1096-9837 (199812)23:12 < 1087::AID-ESP934 > 3.0.CO;2-4.

Aksoy H. 2015. Challenges in modelling sediment matters. In: Heininger P, Cullmann J (eds.). Sediment Matters, 61-81, Springer. DOI: 10.1007/ 978-3-319-14696-6_5. 
Aksoy H, Kavvas ML. 2005. A review of hillslope and watershed scale erosion and sediment transport models. Catena 64: 247-271. DOI:10.1016/j. catena.2005.08.008.

Aksoy H, Unal NE, Cokgor S, Gedikli A, Yoon J, Koca K, Inci SB, Eris E. 2012. A rainfall simulator for laboratory-scale assessment of rainfallrunoff-sediment transport processes over a two-dimensional flume. $\mathrm{Ca}$ tena 98: 63-72. DOI:10.1016/j.catena.2012.06.009.

Aksoy H, Unal NE, Cokgor S, Gedikli A, Yoon J, Koca K, Inci SB, Eris E Pak G. 2013. Laboratory experiments of sediment transport from bare soil with a rill. Hydrological Sciences Journal 58(7): 1505-1518. DOI:10.1080/02626667.2013.824085.

Arjmand Sajjadi S, Mahmoodabadi M. 2015. Aggregate breakdown and surface seal development influenced by rain intensity, slope gradient and soil particle size. Solid Earth 6(1): 311-321. DOI:10.5194/se-6311-2015.

Arguelles ACC, Jung M, Mallari KJB, Pak G, Aksoy H, Kavvas LM, Eris E, Yoon J, Lee Y, Hong S. 2014. Evaluation of an erosion-sediment transport model for a hillslope using laboratory flume data. Journal of Arid Land 6(6): 647-655. DOI:10.1007/s40333-014-0066-9.

Araujo JC, Güntner A, Bronstert A. 2006. Loss of reservoir volume by sediment deposition and its impact on water availability in semiarid Brazil. Hydrological Sciences Journal 51(1): 157-170. DOI:10.1623/ hysj.51.1.157.

Baban SMJ, Yusof KW. 2001. Modeling soil erosion in tropical environments using remote sensing and geographical information systems. $\mathrm{Hy}$ drological Sciences Journal 46(2): 191-198. DOI:10.1080/ 02626660109492815.

Beasley DB, Huggins LF, Monke EJ. 1980. ANSWERS: a model for watershed planning. Trans. ASAE 23(4): 938-944. DOI:10.13031/2013.34692.

Ben Slimane A, Raclot D, Evrard O, Sanaa M, Lefevre I, Bissonnais Y. 2015. Relative contribution of rill/interrill and gully/channel erosion to small reservoir siltation in Mediterranean environments. Land Degradation and Development 27(3): 785-797. DOI:10.1002/ldr.2387.

Biswas H, Raizada A, Mandal D, Kumar S, Srinivas S, Mishra PK. 2015 Identification of areas vulnerable to soil erosion risk in India using GIS methods. Solid Earth 6(4): 1247-1257. DOI:10.5194/se-6-1247-2015.

Bogardi J. 1974. Sediment transport in alluvial streams. Akademiai Kiado: Budapest.

Boix-Fayos C, Martinez-Mena M, Calvo-Cases A, Castillo V, Albaladejo J. 2005. Concise review of interrill erosion studies in SE Spain (alicante and murcia): erosion rates and progress of knowledge from the 1980s. Land Degradation and Development 16: 517-528. DOI:10.1002/ldr.706.

Bravo-Espinosa M, Mendoza ME, Carlon Allende T, Medina L, SaenzReyes JT, Paez R. 2014. Effects of converting forest to avocado orchards on topsoil properties in the trans-mexican volcanic system, Mexico. Land Degradation and Development 25: 452-467.

Cerda A, Garcia-Fayos P. 1997. The influence of slope angle on sediment, water and seed losses on badland landscpaes. Geomorphology 18: 77-90. DOI:10.1002/ldr.2163.

Cerda A, González-Pelayo O, Giménez-Morera A, Jordán A, Pereira P, Novara A, Brevik EC, Prosdocimi M, Mahmoodabadi M, Keesstra S, García Orenes F, Ritsema C. 2016. The use of barley straw residues to avoid high erosion and runoff rates on persimmon plantations in Eastern Spain under low frequency - high magnitude simulated rainfall events. Soil Research 54(2): 154-165. DOI:10.1071/SR15092.

Christiansen JE. 1941. The uniformity of application of water by sprinkler system. Agricultural Engineering 22: 89-92.

Dai Q, Liu Z, Shao H, Yang Z. 2015. Karst bare slope soil erosion and soil quality: a simulation case study. Solid Earth 6(3): 985-995. DOI:10.5194/se-6-985-2015.

Erkossa T, Wudneh A, Desalegn B, Taye G. 2015. Linking soil erosion to on-site financial cost: lessons from watersheds in the Blue Nile basin. Solid Earth. 6: 765-774. DOI:10.5194/sed-7-565-2015.

Ferreira V, Panagopoulos T, Andrade R, Guerrero C, Loures L. 2015. Spatial variability of soil properties and soil erodibility in the Alqueva reservoir watershed. Solid Earth 6: 383-392. DOI:10.5194/se-6-3832015 .

Garde RJ, Ranga Raju KG. 1977. Mechanics of sediment transportation and alluvial stream problems. Wiley Eastern: New Delhi.

Gilley JE, Kincaid DC, Elliot WJ, Laflen JM. 1992. Sediment delivery on rill and interrill areas. Journal of Hydrology 140: 313-341. DOI:10.1016/0022-1694(92)90246-R.

Goldberg DE. 1989. Genetic algorithms in search, optimization, and machine learning. Addison-Wesley: USA.
Govindaraju RS, Kavvas ML, Tayfur G, Krone R. 1992. Erosion control of decomposed granite at Buckhorn Summit. Final Project Report, University of California: Davis, CA.

Grismer ME. 2011. Rainfall simulation studies - a review of designs, performance and erosion measurement variability. Draft Report: UC Davis, Calif.

Haregeweyn N, Poesen J, Verstraeten G, Govers G, de Vente J, Nyssen J, Deckers J, Moeyersons J. 2013. Assessing the performance of a spatially distributed soil erosion and sediment delivery model (WATEM/SEDEM) in Northern Ethiopia. Land Degradation and Development 24: 188-204. DOI:10.1002/ldr.1121.

Julien PY. 2010. Erosion and sedimentation. Cambridge University Press: Cambridge.

Julien PY, Simons DB. 1985. Sediment transport capacity of overland flow. Trans. ASAE 28(3): 755-762. DOI:10.13031/2013.32333.

Kavvas ML, Yoon JY, Chen ZQ, Liang L, Dogrul EC, Ohara N, Aksoy H, Anderson ML, Reuters J, Hackley S. 2006. Watershed environmental hydrology model: environmental module and its application to a California watershed. Journal of Hydrological Engineering 11(3): 261-272. DOI:10.1061/(ASCE)1084-0699(2006)11:3(261).

Keesstra SD, Bouma J, Wallinga J, Tittonell P, Smith P, Cerda A, Montanarella L, Quinton JN, Pachepsky Y, van der Putten WH, Bardgett RD, Moolenaar S, Mol G, Jansen B, Fresco LO. 2016a. The significance of soils and soil science towards realization of the United Nations sustainable development goals. SOIL 2: 111-128. DOI:10.5194/soil-2-111-2016.

Keesstra S, Pereira P, Novara A, Brevik EC, Azorin-Molina C, ParrasAlcantara L, Jordan A, Cerda A. 2016b. Effects of soil management techniques on soil water erosion in apricot orchards. Science of the Total Environment 551-552: 357-366. DOI:10.1016/j.scitotenv.2016.01.182.

Kincaid DC, Solomon KH, Oliphant JC. 1996. Drop size distribution for irrigation sprinklers. Transactions of ASAE 39(3): 839-845. DOI: $10.13031 / 2013.27568$

Kirkby MJ, Abrahart R, McMahon MD, Shao J, Thornes JB. 1998. MEDALUS soil erosion models for global change. Geomorphology 24 (1): 35-49. DOI:10.1016/S0169-555X(97)00099-8

Lassu T, Seeger M, Peters P, Keesstra SD. 2015. The Wageningen rainfall simulator: set-up and calibration of an indoor nozzle-type rainfall simulator for soil erosion studies. Land Degradation and Development 26(6): 604-612. DOI:10.1002/1dr.2360.

Leh M, Bajwa S, Chaubey I. 2013. Impact of land use change on erosion risk: an integrated remote sensing, geographic information system and modeling methodology. Land Degradation and Development 24: 409-421. DOI:10.1002/ldr.1137.

Li XH, Yang J, Zhao CY, Wang B. 2014. Runoff and sediment from orchard terraces in southeastern China. Land Degradation and Development 25: 184-192. DOI:10.1002/ldr.1160.

Lieskovsky J, Kenderessy P. 2014. Modelling the effect of vegetation cover and different tillage practices on soil erosion in vineyards: a case study in Vráble (Slovakia) using WATEM/SEDEM. Land Degradation and Development 25: 288-296. DOI:10.1002/ldr.2162.

Liong SY, Chan WT, ShreeRam J. 1995. Peak flow forecasting with genetic algorithm and SWMM. Journal of Hydraulic Engineering 121(8): 613-617. DOI:10.1061/(ASCE)0733-9429(1995)121:8(613).

Mandal D, Sharda VN. 2013. Appraisal of soil erosion risk in the eastern Himalayan region of India for soil conservation planning. Land Degradation and Development 24: 430-437.

Moazed H, Bavi A, Boroomand-Nasab S, Naseri A, Albaji M. 2010. Effects of climatic and hydraulic parameters on water uniformity coefficient in solid set systems. Journal of Applied Science 10(16): 1792-1796. DOI:10.3923/jas.2010.1792.1796.

Moreno-Ramón H, Quizembe SJ, Ibáñez-Asensio S. 2014. Coffee husk mulch on soil erosion and runoff: experiences under rainfall simulation experiment. Solid Earth 5(2): 851-862. DOI:10.5194/se-5-851-2014.

Musinguzi P, Ebanyat P, Tenywa JS, Basamba TA, Tenywa MM, Mubiru D. 2015. Precision of farmer-based fertility ratings and soil organic carbon for crop production on a Ferralsol. Solid Earth 6(3): 1063-1073. DOI: $10.5194 /$ se-6-1063-2015.

Novotny V, Chesters G. 1989. Delivery of sediment and pollutants from nonpoint sources: a water quality perspective. Journal of Soil and Water Conservation 44(6): 568-576.

Ochoa PA, Fires A, Mejia D, Burneo JI, Ruiz-Sinoga JD, Cerda A. 2016. Effects of climate, land cover and topography on soil erosion risk in a semiarid basin of the Andes. Catena 140: 31-42. DOI:10.1016/j. catena.2016.01.011. 
Pak JH, Fleming M, Scharffenberg W, Gibson S, Brauer T. 2015. Modeling surface soil erosion and sediment transport processes in the Upper North Bosque River Watershed, Texas. Journal of Hydrological Engineering 20(1204015034). DOI:10.1061/(ASCE)HE.1943-5584.0001205.

Palazon L, Gaspar L, Latorre B, Blake WH, Navas A. 2014. Evaluating the importance of surface soil contributions to reservoir sediment in alpine environments: a combined modelling and fingerprinting approach in the Posets-Maladeta Natural Park. Solid Earth. 5: 963-978. DOI:10.5194/ se-5-963-2014.

Pereira P, Cerda A, Lopez AJ, Zavala LM, Mataix-Solera J, Arcenegui V, Misiune I, Keesstra S, Novara A. 2016. Short-term vegetation recovery after a grassland fire in lithuania: the effects of fire severity, slope position and aspect. Land Degradation and Development. DOI:10.1002/ ldr.2498.

Phien HN. 1981. Reservoir sedimentation with correlated inflows. Journal of Hydrology 53: 327-341. DOI:10.1016/0022-1694(81)90009-3.

Phien HN, Arbhabhirama A. 1979. A statistical analysis of the sediment accumulation in Reservoirs. Journal of Hydrology 44: 231-240. DOI:10.1016/0022-1694(79)90133-1.

Pimentel D. 2006. Soil erosion: a food and environmental threat. Environment, Development and Sustainability 8: 119-137. DOI:10.1007/ s10668-005-1262-8.

Prosdocimi M, Cerda A, Tarolli P. 2016. Soil water erosion Mediterranean vineyards: a review. Catena 141: 1-21. DOI:10.1016/j. catena.2016.02.010

Prosser IP, Rustomji P. 2000. Sediment transport capacity relations for overland flow. Progress in Physical Geography 24(2): 179-193. DOI:10.1177/030913330002400202.

Sadeghi SH, Abdollahi Z, Darvishan AK. 2013. Experimental comparison of some techniques for estimating natural raindrop size distribution on the south coast of the Caspian Sea, Iran. Hydrological Sciences Journal 58(6): 1374-1382. DOI:10.1080/02626667.2013.814917.

Sadeghi SHR, Gholami L, Homaee M, Khaledi DA. 2015. Reducing sediment concentration and soil loss using organic and inorganic amendments at plot scale. Solid Earth 6(2): 445-455. DOI:10.5194/se-6-4452015.

Seutloali KE, Beckedahl HR. 2015. Understanding the factors influencing rill erosion on roadcuts in the south eastern region of South Africa. Solid Earth 6(2): 633-641. DOI:10.5194/se-6-633-2015.

Stanchi S, Falsone G, Bonifacio E. 2015. Soil aggregation, erodibility, and erosion rates in mountain soils (NW Alps, Italy). Solid Earth 6: 403-414. DOI:10.5194/se-6-403-2015.

Tayfur G. 2001. Modelling two dimensional erosion process over infiltrating surfaces. Journal of Hydrological Engineering 6(3): 259-262. DOI:10.1061/(ASCE)1084-0699(2001)6:3(259).

Tayfur G. 2002. Artificial neural networks for sheet sediment transport. Hydrological Sciences Journal 47(6): 879-892. DOI:10.1080/ 02626660209492997

Tayfur G. 2012. Soft computing in water resources engineering: artificial neural network, fuzzy logic and genetic algorithm. WIT Press: Southampton, UK; 278.
Trujillo-González JM, Torres-Mora MA, Keesstra SD, Breivik EC, Jiménez BR. 2016. Heavy metal accumulation related to population density in road dust samples taken from urban sites under different land uses. Science of the Total Environment 553: 636-642. DOI:10.1016/j. scitotenv.2016.02.101.

Tsozué D, Nghonda JP, Mekem DL. 2015. Impact of land management system on crop yields and soil fertility in Cameroon. Solid Earth 6(3): 10871101. DOI:10.5194/se-6-1087-2015.

Vanacker V, Govers G, Barros S, Poesen J, Deckers J. 2003. The effect of short-term socio-economic and demographic change on land use dynamics and its corresponding geomorphic response with relation to water erosion in a tropical mountainous catchment, Ecuador. Landscape Ecology 18: 1-15. DOI:10.1023/A:1022902914221.

Vaezi AR, Abbasi M, Bussi G, Keesstra S. 2016. Modeling sediment yield in semi-arid pasture micro-catchments, NW Iran. Land Degradation \& DevelopmentIn press . DOI:10.1002/ldr.2526.

Wang J, Huang J, Zhao X, Wu P, Horwath WR, Hongbing L, Zilong J, Chen X. 2016. Simulated study on effects of ground managements on soil water and available nutrients in jujube orchards. Land Degradation and Development 27: 35-42. DOI:10.1002/ldr.2334.

Wang YQ, Shao MA. 2013. Spatial variability of soil physical properties in a region of the Loess Plateau of PR China subject to wind and water erosion. Land Degradation and Development 24: 296-304. DOI:10.1002/ ldr.1128.

Wu Y, Chen J. 2012. Modeling of soil erosion and sediment transport in the East River Basin in southern China. Science of the Total Environment 441: 159-168. DOI:10.1016/j.scitotenv.2012.09.057.

Xie LW, Zhong J, Chen FF, Cao FX, Li JJ, Wu LC. 2015. Evaluation of soil fertility in the succession of karst rocky desertification using principal component analysis. Solid Earth 6: 515-524. DOI:10.5194/se-6-515-2015.

Xu EQ, Zhang HQ. 2014. Characterization and interaction of driving factors in karst rocky desertification: a case study from Changshun, China. Solid Earth 5: 1329-1340. DOI:10.5194/se-5-1329-2014.

Zhang L, O'Neill AL, Lacey S. 1996. Modelling approaches to the prediction of soil erosion in catchments. Environmental Software 11(1-3): 123133. DOI:10.1016/S0266-9838(96)00023-8.

Zhang GH, Liu YM, Han YF, Zhang XC. 2009. Sediment transport and soil detachment on steep slopes: I. Transport capacity estimation. Soil Science Society of America Journal 73(4): 1291-1297. DOI:10.2136/sssaj2008.0145.

Ziadat FM, Taimeh AY. 2013. Effect of rainfall intensity, slope, land use and antecedent soil moisture on soil erosion in an arid environment. Land Degradation and Development 24: 582-590. DOI:10.1002/ldr.2239.

Ziegler AD, Giambelluca TW, Sutherland RA. 2001. Erosion prediction on unpaved mountain roads in northern Thailand: validation of dynamic erodibility modeling using KINEROS2. Hydrological Processes 15: 337-358. DOI:10.1002/hyp.96.

Zuliziana S, Tanuma K, Yoshimura C, Saavedra OC. 2015. Distributed model of hydrological and sediment transport processes in large river basins in Southeast Asia. Hydrology and Earth System Sciences Discussions 12: 6577-6797. DOI:10.5194/hessd-12-6755-2015. 